\title{
Makanan dan strategi pola makan ikan kuniran Upeneus sulphureus, Cuvier (1829) di perairan Teluk Kendari, Sulawesi Tenggara
}

\author{
[Food and feeding strategy of sunrise goatfish Upeneus sulphureus, Cuvier (1829] in Kendari \\ Bay, Southeast Sulawesi] \\ Asriyana $^{凶}$, Nur Irawati \\ Jurusan Manajemen Sumberdaya Perairan, Fakultas Perikanan dan Ilmu Kelautan- Universitas Halu Oleo \\ Jl. HEA Mokodompit Kampus Bumi Tridharma Anduonohu Kendari, \\ Sulawesi Tenggara 93232, Telp./Fax : 0401-3193782
}

Diterima: 8 September 2017; Disetujui: 27 Februari 2018

\begin{abstract}
Abstrak
Pengetahuan tentang makanan dan strategi pola makan adalah penting untuk memahami peran ekologi dan kapasitas produktif populasi ikan. Informasi tersebut sangat penting untuk pengembangan rencana konservasi dan pengelolaan sumber daya ikan. Penelitian ini bertujuan untuk menganalisis makanan dan strategi pola makan ikan kuniran di perairan Teluk Kendari. Pengambilan contoh dilakukan sekali sebulan dari bulan bulan Mei sampai November 2016, dengan jaring insang eksperimental berukuran mata jaring 3/4, 1, 1 1/4, dan 1 1/2 inci. Kebiasaan makanan dianalisis menggunakan metode indeks bagian terbesar, sedangkan strategi pola makan ditentukan melalui metode Costello yang dimodifikasi oleh Amundsen. Jumlah ikan yang terkumpul sebanyak 386 ekor dengan kisaran panjang total 46,0-176,0 mm dan kisaran bobot 3,0-67,1 g. Ikan dikelompokkan kedalam tiga kelompok ukuran yaitu ukuran kecil (46,0-90,0 mm), sedang $(91,0-134,0 \mathrm{~mm})$, dan ukuran besar $(135,0-176,0 \mathrm{~mm})$. Ditemukan 28 jenis organisme makanan dalam saluran pencernaan ikan kuniran. Menu makanan didominasi oleh kelompok fitoplankton genus Thallasiothrix. Ikan kuniran mengalami perubahan makanan yang signifikan sejalan dengan bertambahnya ukuran panjang tubuh dan waktu. Dalam memanfaatkan makanan di perairan, kuniran umumnya mengembangkan strategi pola makan campuran antara generalis dan spesialis. Strategi pola makan generalis dikembangkan untuk memperoleh semua jenis mangsa, kecuali mangsa Thallasiothrix diperoleh dengan strategi pola makan spesialis.
\end{abstract}

Kata penting: generalis, indeks bagian terbesar, kuniran, strategi pola makan, Thallasiothrix

\begin{abstract}
Knowledge of food and feeding strategies are essential to understand the ecological role and productive capacity of fish populations. This information is critical for development of conservation and management plans of fishery resources. This study aimed to analyze the food and feeding strategy of sunrise goatfish in Kendari bay. Sampling was done monthly from May to November 2016, with bottom experimental gillnets with mesh size $3 / 4,1,1 \frac{1}{4}$, and $1 \frac{1 / 2}{2}$ inches. The food habits was analyzed using index of preponderance; while feeding strategy was determined by Amundsen modified Costello method. There were 386 fish with total length and weight ranged from 46.0-176.0 mm and 3.0-67.1 g, respectively. The fish were categorized into 3 groups based on the length sizes. The length sizes were classified into small size $(45.0-69.7 \mathrm{~mm})$, medium size $(69.8-94.3 \mathrm{~mm})$ and large size $(94.4-119.0 \mathrm{~mm})$. Twenty eight species of organisms were found in the digestive system of the sunrise goatfish dominated by the phytoplankton genus Thallasiothrix. The sunrise goatfish has significant dietary changes with increasing total length and time. The sunrise goatfish developed mix feeding strategies; specialist and generalist. Generalist strategy developed for all prey, except Thallasiothrix obtained by spesialist strategy.
\end{abstract}

Keywords: feeding strategy, generalist, index of preponderance, Thallasiothrix, Upeneus sulphureus

\section{Pendahuluan}

Upeneus sulphureus Cuvier (1829), Fa-mily Mullidae di Indonesia dikenal dengan nama kuniran atau biji nangka merupakan sumber daya bernilai ekonomis penting. Ikan ini mempunyai kelimpahan yang cukup besar di perairan Teluk

$\triangle$ Penulis korespondensi

Alamat surel: yanasri76@yahoo.com
Kendari, Sulawesi Tenggara (Asriyana et al. 2009, Asriyana 2011). Ikan kuniran termasuk dalam jenis ikan demersal yang ditunjukkan dengan letak mulut agak ke bawah dan adanya sungut berjumlah dua buah di bagian dagu yang digunakan untuk meraba dalam usaha pencarian makanan (Lagler et al. 1962). Umumnya ikan kuniran hidup di dasar perairan dangkal dengan 
tipe substrat yang berlumpur atau bercampur pasir (Burhanuddin et al. 1984, Sjafei \& Susilawati 2001). Tipe habitat merupakan faktor penting yang memengaruhi strategi pola makan spesies dengan menentukan peluang mencari makan. Seekor ikan mungkin harus memilih antara habitat yang menyediakan mangsa lebih berlimpah dan beragam, tapi mangsanya lebih sulit untuk tertangkap, atau habitat yang memiliki jumlah mangsa kurang, namun kesempatan menangkap mangsa lebih baik (Crowder \& Cooper 1982).

Penelitian tentang makanan ikan khususnya famili Mullidae telah banyak dilakukan (Boraey \& Soliman 1987, Cherif et al. 2011), namun penelitian tentang strategi makan terutama untuk spesies U. sulphureus belum dilakukan. Penelitian yang ada hanya terbatas pada aspek yang berbeda seperti aspek habitat dan persebaran famili Mullidae (Burhanuddin et al. 1984), U. molluccensis (Sjafei \& Susilawati 2001); biologi reproduksi U. molluccensis (Sjafei \& Susilawati 2001), U. sulphureus (Diandria \& Ernawati 2011), Mullus barbatus (Celik \& Torcu 2000, Metin 2005); pertumbuhan U. sulphureus (Boraey \& Soliman 1987, Sumiono \& Nuraini 2007, Diandria \& Ernawati 2011, Asriyana \& Irawati 2017), Mullus barbatus (Cherif et al. 2011), Mullus surmuletus (Arslan \& İşmen 2013, Kherraz et al. 2014). Berdasarkan hal tersebut, maka penelitian ini merupakan penelitian awal aspek strategi pola makan pada ikan kuniran spesies U. sulphureus Cuvier (1829).

Teluk Kendari, Sulawesi Tenggara merupakan suatu wilayah estuaria dengan berbagai aktivitas di dalamnya. Peningkatan aktivitas di sekitar perairan Teluk Kendari diperkirakan dapat mengakibatkan perubahan kondisi ekologis perairan tersebut seperti kualitas air, struktur komunitas fitoplankton, zooplankton, dan organisme bentik. Perubahan kondisi ekologis tersebut selanjutnya dapat memengaruhi populasi ikan seperti yang terjadi di perairan lain (Orpin 2004, Karakassis et al. 2005, Jaureguizar \& Milessi 2008, Asriyana 2011). Penelitian mengenai makanan dan strategi pola makan ikan kuniran dalam ekosistem yang unik ini akan meningkatkan pengetahuan mengenai ekologi ikan. Pemahaman tentang makanan dan strategi pola makanan ikan dapat memberikan informasi mengenai hubungan ekologi diantara organisme perairan seperti bentuk-bentuk pemangsaan, persaingan, dan rantai makanan. Mengingat pentingnya informasi ini, maka penelitian tentang makanan dan strategi pola makan ikan kuniran di perairan Teluk Kendari perlu dilakukan. Penelitian ini bertujuan untuk menganalisis makanan dan strategi pola makan ikan kuniran Upeneus sulphureus di perairan Teluk Kendari.

\section{Bahan dan metode}

Penelitian ini dilaksanakan di perairan Teluk Kendari, Sulawesi Tenggara dari bulan Mei sampai November 2016. Teluk Kendari berada pada $3^{\circ} 57^{\prime} 59,37^{\prime \prime}-3^{\circ} 59^{\prime} 32,39^{\prime \prime}$ LS dan 122 $31^{\prime}$ 38,07”-122³5'55,93” BT (Gambar 1). Stasiun penelitian ditentukan secara horisontal dari wilayah hulu ke hilir Teluk Kendari (Asriyana \& Irawati 2017). Penempatan stasiun dimaksudkan agar contoh ikan yang tertangkap mewakili kondisi populasi ikan kuniran di perairan Teluk Kendari.

Stasiun I, perairan bagian hulu. Stasiun ini banyak menerima masukan air tawar dari empat sungai besar (Mandonga, Kadia, Wanggu, dan Kambu). Selain itu juga mendapat masukan bahan organik dan sedimentasi. Bahan organik berasal dari permukiman penduduk, pertambakan, kegiatan pertanian yang terdapat di sepanjang beberapa sungai besar dan kecil. Sedimentasi cukup tinggi di daerah ini berasal dari hasil aktivitas 


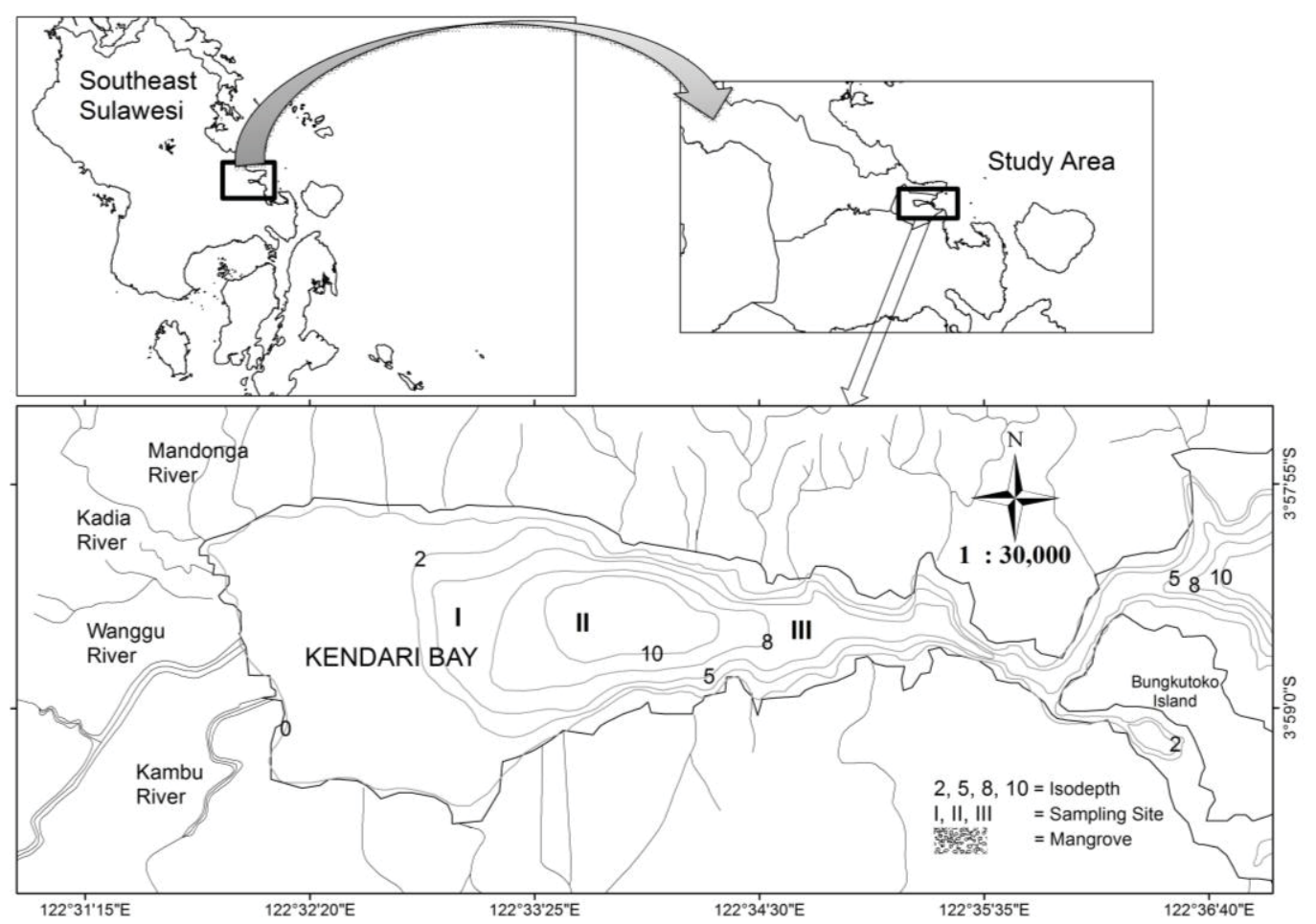

Gambar 1. Lokasi penelitian, Teluk Kendari Sulawesi Tenggara (Asriyana \& Irawati 2017)

penambangan pasir di area sekitar aliran Sungai Wanggu dan Kambu. Kedalaman perairan di stasiun ini maksimal 5 meter.

Stasiun II, perairan bagian tengah, dengan kedalaman sekitar 5 - 10 meter.

Stasiun III, perairan bagian hilir. Stasiun ini berada dekat mulut teluk sehingga lebih banyak dipengaruhi oleh masuknya air laut dari luar Teluk Kendari. Selain itu daerah ini relatif dalam dengan kisaran 5 sampai 8 meter.

Ikan kuniran ditangkap dengan menggunakan jaring insang dasar yang terbuat dari bahan nilon monofilamen dengan panjang $30 \mathrm{~m}$ dan tinggi jaring (dari pelampung sampai pemberat ketika digantung di dalam air) sekitar 2 meter untuk setiap ukuran mata jaring yaitu 3/4, 1, 1 1/4, dan 1 1/2 inci, serta tinggi jaring 7 meter untuk ukuran mata jaring 2 inci. Pengambilan sampel dilakukan setiap bulan di tiga stasiun penelitian.
Seluruh sampel dari setiap ukuran mata jaring digabung dan dikumpul ke dalam kotak berisi es untuk selanjutnya dianalisis di laboratorium.

Di laboratorium, ikan contoh diukur panjang totalnya yaitu panjang ikan dari ujung terdepan bagian kepala hingga ujung terakhir bagian ekor dengan menggunakan papan pengukur ikan berketelitian $1 \mathrm{~mm}$ dan bobotnya ditimbang menggunakan timbangan yang ketelitiannya 0,1g. Selanjutnya ikan dibedah dengan pisau bedah dan saluran pencernaannya dikeluarkan dari rongga tubuh dan diawetkan dalam formalin $5 \%$. Seluruh isi saluran pencernaan makanan ikan diukur volumenya dengan teknik pemindahan air (Effendie 1979). Cara yang sama juga dilakukan untuk mengetahui volume saluran pencernaan. Pemeriksaan makanan kuniran tidak membedakan antara saluran perncernaan ikan jantan dan betina. 
Dalam menganalisis makanan, isi saluran pencernaan makanan setiap individu diletakkan ke dalam cawan petri. Jenis-jenis makanan ikan yang ditemukan dalam saluran pencernaan diamati di bawah mikroskop binokuler dan diidentifikasi menurut Gosner (1971), Yamaji (1979), Higgins \& Thiel (1988), dan Tomas (1997). Kepenuhan lambung ikan kuniran ditentukan berdasarkan perbandingan antara volume material isi lambung dan volume lambung (Cunha et al. 2005). Analisis makanan ikan ditentukan melalui indeks bagian terbesar (Natarajan \& Jhingran 1961), yaitu:

$$
\mathrm{I}_{\mathrm{i}}=\frac{\mathrm{V}_{\mathrm{i}} \times \mathrm{O}_{\mathrm{i}}}{\sum_{\mathrm{i}}^{\mathrm{n}}\left(\mathrm{V}_{\mathrm{i}} \mathrm{xO}_{\mathrm{i}}\right)} \times 100
$$

Keterangan: $\mathrm{I} i=$ indeks bagian terbesar, $\mathrm{Vi}=$ persentase volume makanan jenis ke-I, Oi= persentase frekuensi kejadian makanan jenis ke-I, $n=$ jumlah total organisme makanan $(\mathrm{i}=1,2,3, \ldots . . \mathrm{n})$

Perbedaan jenis makanan alami antarkelompok ukuran dan waktu pengamatan diuji de- ngan statistik non parametrik, Kruskal Wallis dengan tingkat signifikasi $(\alpha)=5 \%$ (Sokal \& Rohlf 1995). Analisis tersebut dikerjakan dengan bantuan paket program software SPSS 10 (Santoso 2003).

Strategi pola makan ikan kuniran ditentukan dengan memplotkan kelimpahan spesifik mangsa dengan persentase frekuensi kejadian seperti tertera pada Gambar 2. Plot yang dihasilkan memberikan informasi tentang pentingnya mangsa, strategi pola makan, dan luas relung yang disimpulkan melalui posisi mangsa dalam diagram. Jika satu atau beberapa mangsa terletak di kanan atas diagram, maka posisi ini akan menunjukkan strategi pola makan spesialis dengan luas relung yang sempit. Namun jika semua mangsa terletak di sepanjang atau di bawah diagonal dari kiri atas ke kanan bawah plot, maka posisi ini menunjukkan strategi pola makan generalis dengan luas relung yang lebar (Amundsen et al. 1996).

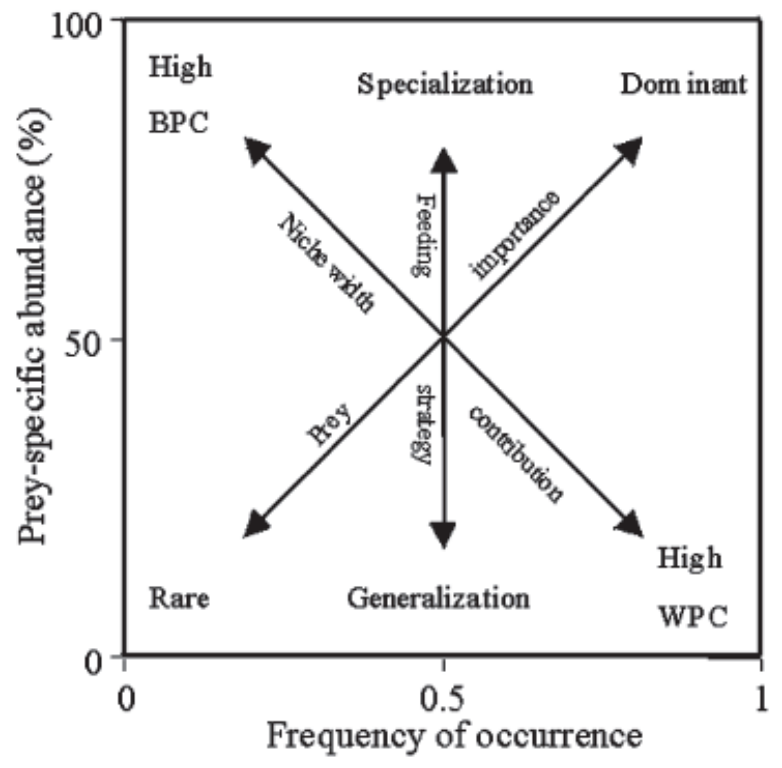

Gambar 2. Plot kelimpahan spesifik organisme makanan dengan frekuensi kejadian modifikasi Costello (Hinz et al. 2005) 
Kelimpahan spesifik organisme makanan dihitung dengan menggunakan metode Costello yang dimodifikasi Amundsen et al. (1996) dan La Mesa et al. (2008):

$$
P_{i}=\left(\frac{\sum_{i} S_{i}}{\sum S_{t i}}\right) \times 100
$$

Keterangan: $\mathrm{P}_{\mathrm{i}}=$ kelimpahan spesifik organisme makanan; $\mathrm{S}_{\mathrm{i}}=$ isi lambung yang berisi organisme makanan ke-i ; $\mathrm{S}_{\mathrm{ti}}=$ total isi lambung yang berisi organisme makanan ke-i, $n=$ jumlah total organisme makanan $(i=$ $1,2,3, \ldots . . \mathrm{n})$

Luas relung ditentukan dengan menggunakan indeks Levin's yang dibakukan (Krebs 1989; Labropoulou \& Papadopoulou-Smith 1999; Novakowski et al. 2008) :

$$
B_{i}=\frac{1}{(n-1)}\left(\left(\frac{1}{\sum_{i, j=1}^{n} p_{i j}}\right)-1\right)
$$

Keterangan : $\mathrm{B}_{\mathrm{i}}=$ luas relung dibakukan; $\mathrm{P}_{\mathrm{ij}}=$ proporsi organisme makanan ke-i oleh kelompok ukuran ke-j; n $=$ jumlah total organisme makanan; Nilai $B_{i}$ bervariasi dari 0 sampai 1 . Nilai $B_{i}$ tinggi apabila $B_{i}>0,6$; moderat apabila nilai $0,4<\mathrm{B}_{\mathrm{i}}<0,6$; dan rendah apabila $\mathrm{B}_{\mathrm{i}}$ $<0,4$.

\section{Hasil}

Kelompok ukuran ikan

Ikan yang tertangkap selama penelitian berjumlah 386 ekor, dengan kisaran panjang total 46,0-176,0 $\mathrm{mm}$ dan bobot 3,0-67,1 g. Ikan tersebut dipisahkan dalam tiga kelompok berdasarkan ukuran panjang yaitu ukuran kecil (46,0-90,0 $\mathrm{mm})$, sedang (91,0-134,0 mm), dan ukuran besar (135,0-176,0 mm). Rincian masing-masing kelompok ukuran tertera pada Tabel 1. Ikan berukuran sedang terlihat mempunyai frekuensi terbesar (50,52\%), diikuti ikan ukuran kecil $(45,34 \%)$ dan ukuran besar (4,15\%).

\section{Komposisi makanan}

Jumlah lambung yang diperiksa dan berisikan makanan adalah 386 buah dan kepenuhan lambung di atas 75\% (Gambar 3). Hasil analisis isi lambung menunjukkan bahwa terdapat 28 organisme makanan yang terbagi dalam empat kelompok, yaitu fitoplankton, zooplankton, makroavertebrata bentik, dan detritus (Tabel 2). Kelompok fitoplankton meliputi 15 genera, zooplankton 11 genera, makro-avertebrata bentik hanya 1 genus, dan detritus. Secara umum, kelompok fitoplankton terlihat mendominasi isi saluran pencernaan ikan kuniran, Ii=68,69 dibanding kelompok makanan lainnya (Tabel 3). Dalam kelompok fitoplankton, genus Thalassiothrix mempunyai nilai indeks paling besar $(\mathrm{Ii}=28,56)$ sedangkan genera lainnya hanya mempunyai nilai $\mathrm{Ii}=0,46-8,16$. Calanus merupakan genus yang mendominasi kelompok zooplankton $(\mathrm{Ii}=4,79)$ dibandingkan genera lainnya $(0,29-4,16)$.

\begin{tabular}{|c|c|c|c|c|c|c|c|c|c|}
\hline \multirow{2}{*}{ Kelompok } & \multirow{2}{*}{$\begin{array}{c}\text { Kisaran panjang } \\
(\mathrm{mm})\end{array}$} & \multicolumn{7}{|c|}{ Bulan } & \multirow{2}{*}{$\begin{array}{l}\text { Total } \\
\text { (ekor) }\end{array}$} \\
\hline & & Mei & Jun & Jul & Agu & Sep & Okt & Nov & \\
\hline Kecil & $46-90$ & 0 & 0 & 6 & 2 & 45 & 115 & 7 & 175 \\
\hline Sedang & $91-134$ & 2 & 1 & 3 & 14 & 26 & 57 & 92 & 195 \\
\hline Besar & $135-176$ & 3 & 0 & 0 & 4 & 3 & 6 & 0 & 16 \\
\hline \multicolumn{2}{|r|}{ Total } & 5 & 1 & 9 & 20 & 74 & 178 & 99 & 386 \\
\hline
\end{tabular}

Tabel 1. Jumlah ikan pada setiap kelompok ukuran 


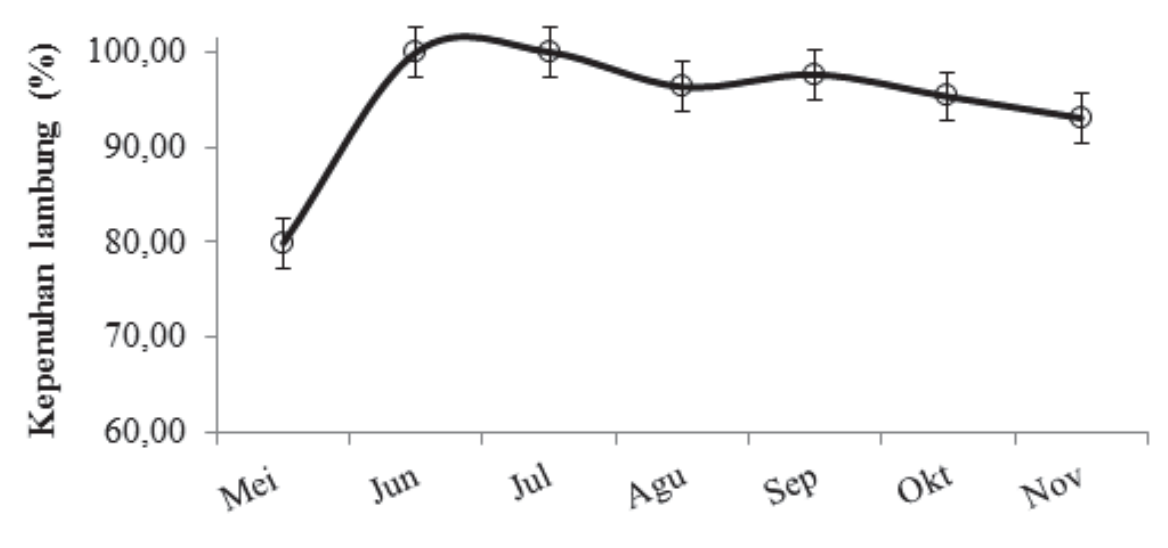

Bulan

Gambar 3. Persentase kepenuhan lambung ikan kuniran tiap bulan di Teluk Kendari

Tabel 2. Organisme makanan ikan kuniran

\begin{tabular}{ll}
\hline \multicolumn{1}{c}{ Kelompok } & \multicolumn{1}{c}{ Jenis } \\
\hline Fitoplankton & $\begin{array}{l}\text { Ankistrodesmus, Ceratium, Coscinodiscus, Guinardia, Istmia, } \\
\text { Leptoselindris, Licmophora, Nitzschia, Raphidinium, Rhizosolenia, } \\
\text { Selenastrum, Spirulina, Thalassiothrix, Thallassiosira, } \\
\text { Trichodesmium }\end{array}$ \\
& $\begin{array}{l}\text { Acartia, Calanus, Candaina, Creses, Euphasia, Lucifer, Microsetella, } \\
\text { Zooplankton }\end{array}$ \\
& Nauplius, Neomysis, Pacudo zon, Zoea \\
Makro-avertebrata bentik & Helisoma \\
Detritus & - \\
\hline
\end{tabular}

Terdapat perbedaan signifikan komposisi makanan antarukuran ikan (uji Kruskal-Wallis pada taraf kepercayaan 95\%, [P <0,05; $\alpha=5 \%$, $\mathrm{db}=\mathrm{n}-2])$ (Tabel 4). Kelompok ikan kuniran ukuran kecil (46,0-90,0 mm) memanfaatkan 12 organisme makanan dan didominasi oleh kelompok fitoplankton terutama genus Thalassiothrix $(\mathrm{Ii}=31,42)$, sedangkan kelompok zooplankton didominasi oleh genus Lucifer $(\mathrm{Ii}=8,36)$. Kelompok ikan berukuran sedang (91,0-134,0 mm) memanfaatkan 24 organisme makanan dan didominasi oleh kelompok fitoplankton dari genus Thalassiothrix $(\mathrm{Ii}=13,70)$, sementara kelompok zooplankton didominasi oleh genus Lucifer $(\mathrm{Ii}=6,73)$. Kelompok ikan berukuran besar (135,0-176,0 mm) memanfaatkan 22 organisme dan didominasi oleh kelompok fitoplankton dari genus Thalassiothrix ( $\mathrm{Ii}=12,87)$, sementara kelompok zooplankton didominasi oleh genus $\mathrm{Mi}$ crosetella $(\mathrm{Ii}=5,92)$. Variasi jumlah jenis makanan terlihat berbeda mengikuti pertambahan panjang, namun dominasi makanan ikan kuniran tetap berasal dari kelompok fitoplankton. Dengan bertambahnya ukuran panjang, secara gradual nilai Ii Thalassiothrix semakin rendah (Tabel 4).

Secara umum kisaran nilai luas relung ikan kuniran relatif kecil $(0,15-0,28)$. Walaupun demikian, makanan ikan kuniran semakin beragam dengan bertambahnya ukuran dan sempurnanya organ pencernaan.

Makanan ikan kuniran berdasarkan bulan pengamatan menunjukkan perbedaan signifikan 
Tabel 3. Indeks bagian terbesar makanan ikan kuniran

\begin{tabular}{|c|c|c|}
\hline Kelompok & $\begin{array}{l}\text { Organisme } \\
\text { makanan }\end{array}$ & $\mathrm{Ii}$ \\
\hline \multirow[t]{16}{*}{ Fitoplankton } & Ankistrodesmus & 4,72 \\
\hline & Ceratium & 2,50 \\
\hline & Coscinodiscus & 3,29 \\
\hline & Guinardia & 1,94 \\
\hline & Istmia & 5,97 \\
\hline & Leptoselindris & 8,16 \\
\hline & Licmophora & 0,85 \\
\hline & Nitzschia & 2,46 \\
\hline & Raphidinium & 1,14 \\
\hline & Rhizosolenia & 3,22 \\
\hline & Selenastrum & 1,46 \\
\hline & Spirulina & 3,49 \\
\hline & Thalassiothrix & 28,56 \\
\hline & Thallassiosira & 0,46 \\
\hline & Trichodesmium & 0,46 \\
\hline & & 68,69 \\
\hline \multirow[t]{12}{*}{ Zooplankton } & Acartia & 2,86 \\
\hline & Calanus & 4,79 \\
\hline & Candaina & 0,38 \\
\hline & Creses & 1,92 \\
\hline & Euphasia & 4,16 \\
\hline & Lucifer & 2,55 \\
\hline & Microsetella & 1,59 \\
\hline & Nauplius & 1,32 \\
\hline & Neomysis & 0,29 \\
\hline & Pacudo zon & 2,12 \\
\hline & Zoea & 1,43 \\
\hline & & 23,42 \\
\hline \multirow[t]{2}{*}{$\begin{array}{l}\text { Makro-avertebrata } \\
\text { bentik }\end{array}$} & Helisoma & 0,83 \\
\hline & & $\mathbf{0 , 8 3}$ \\
\hline \multirow[t]{2}{*}{ Detritus } & - & 7,06 \\
\hline & & 7,06 \\
\hline Total & & 100,00 \\
\hline
\end{tabular}

(uji Kruskal-Wallis pada taraf kepercayaan 95\%, $[\mathrm{P}<0,05 ; \alpha=5 \%, \mathrm{db}=\mathrm{n}-2])$ (Tabel 5). Genus Thallasiothrix adalah makanan yang ditemukan setiap bulan dengan frekuensi kejadian $100 \%$ dan dapat digolongkan sebagai makanan yang berperan penting terhadap ikan kuniran. Sebaliknya jenis makanan lain ditemukan dengan frekuensi kejadian 14-57\%, kecuali genera Leptocylindrus (86\%) dan Calanus (71\%).

\section{Strategi pola makan}

Saat berukuran kecil, ikan kuniran memiliki mangsa Thallasiothrix yang terletak di kanan atas diagram dengan kelimpahan spesifik di atas $50 \%$ dan frekuensi kejadian 100\% (Gambar 4). Hal ini menunjukkan bahwa Thallasiothrix memiliki peran penting dalam menu makanan kuniran. Saat berukuran kecil tersebut, ikan kuniran mengembangkan strategi pola makan spesialis. Selain mengembangkan strategi pola makan spesialis, ikan kuniran tersebut juga mengembangkan strategi pola makan generalis. Hal ini ditunjukkan oleh posisi 11 organisme mangsa yang terletak di sepanjang atau di bawah diagonal dari kiri atas ke kanan bawah plot.

Saat berukuran sedang, kuniran juga menunjukkan strategi pola makan spesialis dan generalis. Strategi pola makan spesialis dikembangkan untuk memperoleh mangsa dari genera Coscinodiscus dan Licmophora, sebaliknya strategi pola makan generalis dikembangkan dalam memperoleh mangsa lainnya (22 mangsa).

Saat berukuran besar, ikan kuniran hanya mengembangkan strategi pola makan generalis untuk memperoleh mangsanya di perairan (22 mangsa). Strategi makan ikan kuniran juga terlihat dari luas relung makanan. Walaupun kisaran nilai luas relung relatif rendah $\left(\mathrm{B}_{\mathrm{i}}=0,15-0,28\right)$, namun ikan kuniran umumnya menerapkan strategi generalis dalam memanfaatkan mangsa yang ada di perairan.

Berdasarkan bulan pengamatan, ikan kuniran mengembangkan strategi pola makan generalis (Gambar 5) dalam memperoleh mangsa di perairan, kecuali saat bulan Juli, Agustus, dan Oktober 2016 juga mengembangkan strategi pola makan spesialis. Strategi pola makan spesialis dikembangkan saat mengambil mangsa dari genus Thalassiothrix, sedangkan mangsa lainnya diperoleh dengan mengembangkan strategi pola makan generalis. 
Tabel 4. Makanan ikan kuniran berdasarkan kelompok ukuran

\begin{tabular}{|c|c|c|c|c|}
\hline \multirow{2}{*}{ Kelompok } & \multirow{2}{*}{ Organisme Makanan } & \multicolumn{3}{|c|}{ Indeks Bagian Terbesar / Kelompok Ukuran } \\
\hline & & $46,0-90,0$ & $91,0-134,0$ & $135,0-176,0$ \\
\hline \multirow[t]{16}{*}{ Fitoplankton } & Ankistrodesmus & & 3,21 & 4,12 \\
\hline & Ceratium & & 5,40 & \\
\hline & Coscinodiscus & 11,85 & 4,35 & 4,12 \\
\hline & Guinardia & & 3,34 & 6,17 \\
\hline & Istmia & & 5,64 & 7,42 \\
\hline & Leptoselindris & 6,72 & 6,49 & 5,16 \\
\hline & Licmophora & & 2,02 & \\
\hline & Nitzschia & 3,89 & 4,26 & 7,70 \\
\hline & Raphidinium & & 2,82 & 3,86 \\
\hline & Rhizosolenia & & 2,37 & 4,63 \\
\hline & Selenastrum & & 1,83 & 2,84 \\
\hline & Spirulina & 1,84 & & 6,04 \\
\hline & Thalassiothrix & 31,42 & 13,70 & 12,87 \\
\hline & Thallassiosira & & & 2,71 \\
\hline & Trichodesmium & & 1,69 & 2,71 \\
\hline & & 55,71 & 57,10 & 70,33 \\
\hline \multirow[t]{12}{*}{ Zooplankton } & Acartia & 3,57 & 2,78 & 4,74 \\
\hline & Calanus & 6,38 & 5,24 & 3,16 \\
\hline & Candaina & & 2,56 & \\
\hline & Creses & & 4,92 & 1,61 \\
\hline & Euphasia & 8,13 & 5,39 & 4,15 \\
\hline & Lucifer & 8,36 & 6,73 & 2,54 \\
\hline & Microsetella & & & 5,92 \\
\hline & Nauplius & & 2,43 & 2,06 \\
\hline & Neomysis & & 1,92 & \\
\hline & Pacudo zon & 5,30 & 4,13 & \\
\hline & Zoea & 7,90 & 2,75 & \\
\hline & & 39,65 & 38,85 & 24,20 \\
\hline \multirow[t]{2}{*}{ Makro-avertebrata bentik } & Helisoma & & & 3,09 \\
\hline & & $\mathbf{0 , 0 0}$ & $\mathbf{0 , 0 0}$ & 3,09 \\
\hline \multirow[t]{2}{*}{ Detritus } & - & 4,61 & 4,06 & 2,35 \\
\hline & & 4,61 & 4,06 & 2,35 \\
\hline Total & & $\mathbf{1 0 0 , 0}$ & 100,0 & 100,0 \\
\hline \multicolumn{5}{|c|}{ Kruskal-Wallis $=\mathrm{P}<0,05(\alpha=5 \%, \mathrm{db}=\mathrm{n}-2)$} \\
\hline
\end{tabular}

Tabel 5. Indeks bagian terbesar organisme makanan ikan kuniran setiap bulan di perairan Teluk Kendari pada bulan Mei - November 2016

\begin{tabular}{|c|c|c|c|c|c|c|c|c|}
\hline \multirow{2}{*}{ Kelompok } & \multirow{2}{*}{$\begin{array}{c}\text { Organisme } \\
\text { Makanan }\end{array}$} & \multicolumn{7}{|c|}{ Indeks Bagian Terbesar/Waktu (Bulan) } \\
\hline & & Mei & Juni & Juli & Agu. & Sept. & Okt. & Nov. \\
\hline \multirow[t]{16}{*}{ Fitoplankton } & Ankistrodesmus & 7,73 & 17,89 & & 2,54 & & 4,89 & \\
\hline & Ceratium & & & & 14,01 & & 3,67 & \\
\hline & Coscinodiscus & 7,73 & & & 2,02 & & 2,73 & 10,52 \\
\hline & Guinardia & 11,59 & & & 2,01 & & & \\
\hline & Istmia & & & & 4,92 & 17,62 & 2,44 & 16,84 \\
\hline & Leptoselindris & 9,66 & & 10,04 & 4,30 & 12,10 & 6,67 & 14,33 \\
\hline & Licmophora & & 5,96 & & & & & \\
\hline & Nitzschia & & & 5,94 & 6,50 & & 4,79 & \\
\hline & Raphidinium & & & & 4,01 & & 3,95 & \\
\hline & Rhizosolenia & 8,69 & 11,93 & & 1,90 & & & \\
\hline & Selenastrum & & & & 2,15 & 5,91 & 2,14 & \\
\hline & Spirulina & 17,39 & & 2,82 & & & 4,25 & \\
\hline & Thalassiothrix & 10,63 & 49,67 & 51,75 & 18,81 & 24,43 & 23,88 & 20,75 \\
\hline & Thallassiosira & & & & 3,24 & & & \\
\hline & Trichodesmium & & & & 3,24 & & & \\
\hline & & 73,43 & 85,45 & 70,55 & 69,65 & 60,06 & $\mathbf{5 9 , 4 2}$ & 62,43 \\
\hline
\end{tabular}


Tabel 5 (lanjutan). Indeks bagian terbesar organisme makanan ikan kuniran setiap bulan di perairan Teluk Kendari pada bulan Mei - November 2016

\begin{tabular}{|c|c|c|c|c|c|c|c|c|}
\hline \multirow[t]{12}{*}{ Zooplankton } & Acartia & & & 4,90 & 1,42 & 9,86 & 3,81 & \\
\hline & Calanus & 3,87 & & 11,07 & 1,94 & 8,87 & 7,77 & \\
\hline & Candaina & & & & 2,69 & & & \\
\hline & Creses & & & & 1,60 & & 3,41 & 8,40 \\
\hline & Euphasia & & & & 3,42 & 10,85 & 7,45 & 7,43 \\
\hline & Lucifer & & & & 3,81 & & 6,40 & 7,64 \\
\hline & Microsetella & 11,12 & & & & & & \\
\hline & Nauplius & & & & 2,04 & 2,96 & 4,26 & \\
\hline & Neomysis & & & & 2,02 & & & \\
\hline & Pacudo zon & & & 7,23 & 7,64 & & & \\
\hline & Zoea & & & & & & 2,82 & 7,22 \\
\hline & & 14,98 & $\mathbf{0 , 0 0}$ & 23,20 & 26,59 & 32,54 & 35,93 & 30,68 \\
\hline \multirow{2}{*}{$\begin{array}{l}\text { Makro- } \\
\text { avertebrata } \\
\text { bentik }\end{array}$} & Helisoma & 5,80 & & & & & & \\
\hline & & 5,80 & 0,00 & 0,00 & $\mathbf{0 , 0 0}$ & 0,00 & $\mathbf{0 , 0 0}$ & 0,00 \\
\hline \multirow[t]{2}{*}{ Detritus } & - & 5,80 & 14,55 & 6,25 & 3,78 & 7,46 & 4,71 & 6,90 \\
\hline & & 5,80 & 14,55 & 6,25 & 3,78 & 7,46 & 4,71 & 6,90 \\
\hline \multirow[t]{2}{*}{ Total } & & 100,00 & 100,00 & 100,00 & 100,00 & 100,06 & 100,00 & 100,00 \\
\hline & & kal-Wal & $\mathrm{S}=\mathrm{P}<$ & $05(\alpha=5$ & $\mathrm{db}=\mathrm{n}-2$ & & & \\
\hline
\end{tabular}
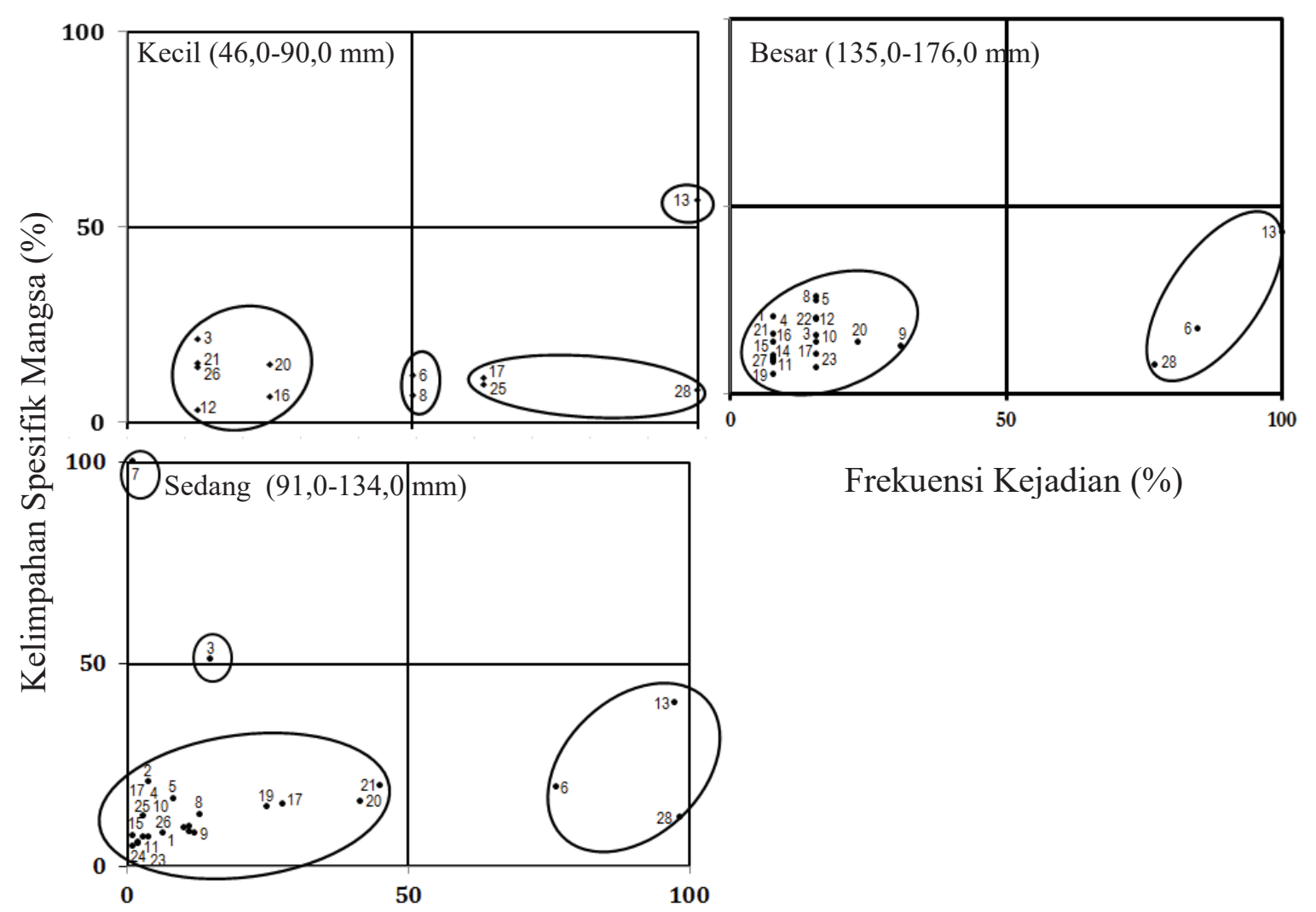

Frekuensi Kejadian (\%)

Gambar 4. Strategi makan ikan kuniran berdasarkan kelompok ukuran. Mangsa: 1. Ankistrodesmus, 2. Ceratium, 3. Coscinodiscus, 4. Guinardia, 5. Istmia, 6. Leptoselindris, 7. Licmophora, 8. Nitzschia, 9. Raphidinium, 10. Rhizosolenia, 11. Selenastrum, 12. Spirulina, 13. Thalassiothrix, 14. Thallassiosira, 15. Trichodesmium, 16. Acartia, 17. Calanus, 18. Candaina, 19. Creses, 20. Euphasia, 21. Lucifer, 22. Microsetella, 23. Nauplius, 24. Neomysis, 25. Pacudo zon, 26. Zoea, 27. Helisoma, 28. Detritus 

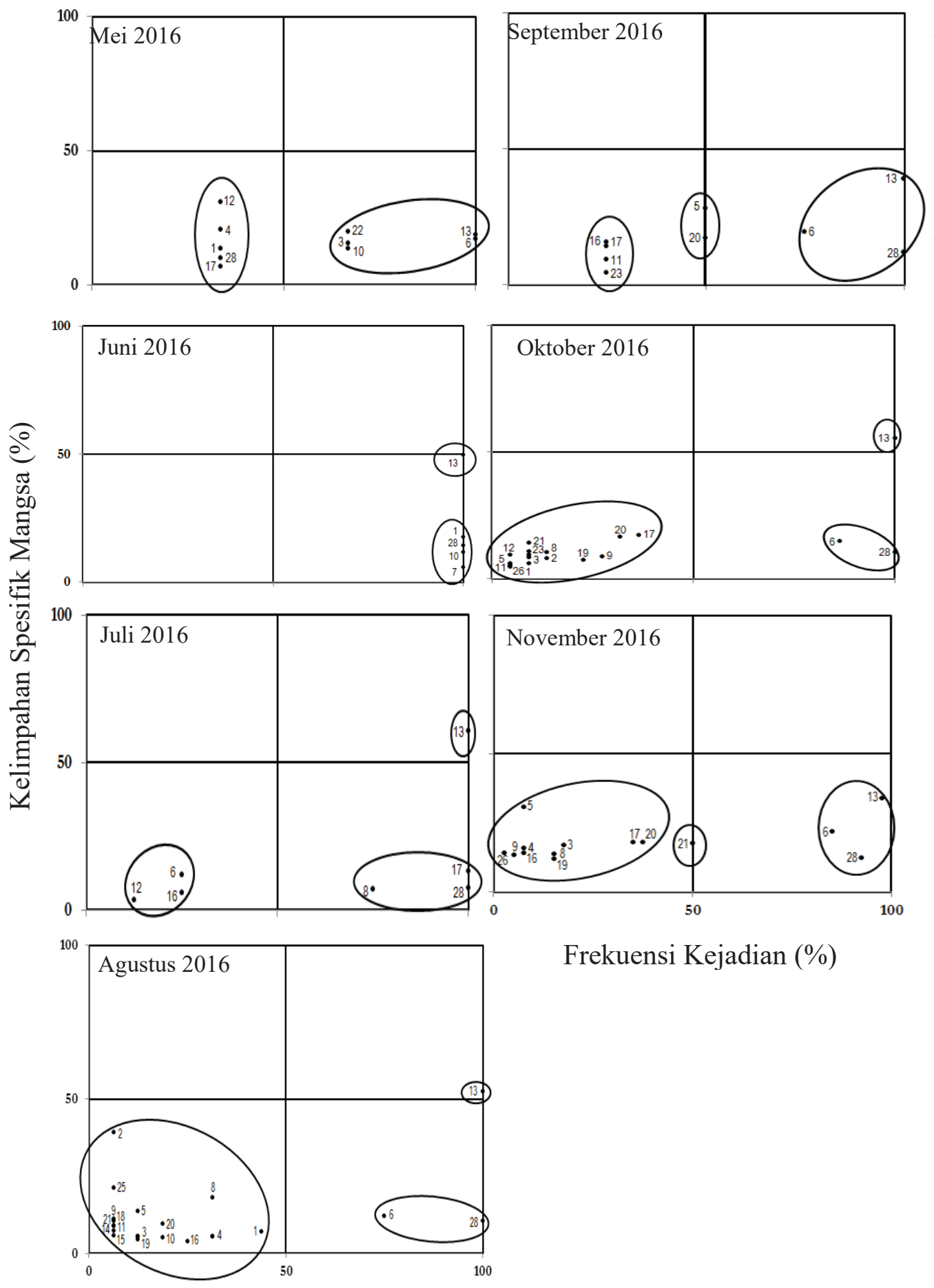

Frekuensi Kejadian (\%)

Gambar 5. Strategi makan ikan kuniran berdasarkan bulan pengamatan. Mangsa: 1. Ankistrodesmus, 2. Ceratium, 3. Coscinodiscus, 4. Guinardia, 5. Istmia, 6. Leptoselindris, 7. Licmophora, 8. Nitzschia, 9. Raphidinium, 10. Rhizosolenia, 11. Selenastrum, 12. Spirulina, 13. Thalassiothrix, 14. Thallassiosira, 15. Trichodesmium, 16. Acartia, 17. Calanus, 18. Candaina, 19. Creses, 20. Euphasia, 21. Lucifer, 22. Microsetella, 23. Nauplius, 24. Neomysis, 25. Pacudo zon, 26. Zoea, 27. Helisoma, 28. Detritus 


\section{Pembahasan}

Kelompok ukuran ikan

Kelimpahan ikan kuniran ukuran sedang selama penelitian di perairan Teluk Kendari lebih besar dibanding kelompok ukuran lainnya. Kondisi ini berhubungan dengan kondisi perairan Teluk Kendari yang menyediakan tempat perlindungan dan pembesaran bagi ikan kuniran. Kondisi tersebut didukung oleh tersedianya daerah makanan dan pembesaran di sekitar Stasiun I yang banyak ditumbuhi mangrove. Tumbuhan mangrove memberikan tempat berlindung dari predator sehingga menarik perhatian ikan-ikan muda untuk menggunakan daerah ini sebagai daerah asuhan dan pembesaran. Selain itu adanya partikel-partikel serasah yang dihasilkan tumbuhan mangrove merupakan sumber makanan bagi biota perairan yang menggunakan daerah ini sebagai habitat, daerah asuhan, dan pembesaran (Blaber \& Blaber 1980, Beck et al. 2001, Elliott \& Hemingway 2002, Baker \& Sheaves 2005, Jin et al. 2007, Asriyana et al. 2009, Green et al. 2009, Wang et al. 2009, Nanjo et al. 2014, Edworthy \& Strydom 2016). Umumnya ikan estuari bermigrasi saat pasang ke daerah lumpur intertidal, yang menyediakan sumber daya makanan yang melimpah. Wilayah intertidal estuari, umumnya dianggap sebagai daerah pembibitan karena menyediakan makanan dan perlindungan bagi ikan laut remaja dari serangan predator (Asriyana et al. 2004, Olivera et al. 2004, Rahardjo et al. 2006, Edworthy \& Strydom 2016). Berdasarkan hal tersebut maka dapat dinyatakan bahwa perairan Teluk Kendari digunakan oleh ikan kuniran sebagai daerah asuhan dan pembesaran.

\section{Komposisi makanan}

Secara umum, fitoplankton merupakan kelompok makanan yang berperan penting dalam kehidupan ikan kuniran $(\mathrm{Ii}=68,69)$. Hasil analisis makanan menunjukkan bahwa dari kelompok fitoplankton, genus Thalassiothrix mempunyai indeks bagian terbesar paling besar $(\mathrm{Ii}=28,56)$ dan diikuti oleh Leptocylindrus $(\mathrm{Ii}=8,16)$ (Tabel 3). Hal ini berarti kedua organisme makanan tersebut merupakan makanan yang berperan penting untuk ikan kuniran. Walaupun kelompok zooplankton, makro-avertebrata bentik, dan detritus merupakan makanan ikan kuniran, namun ketiga kelompok tersebut memiliki nilai indeks bagian terbesar yang rendah $(\mathrm{Ii}=<8,00)$ dibandingkan kelompok fitoplankton. Tingginya nilai kelompok fitoplankton tersebut disebabkan oleh kelimpahan fitoplankton terutama famili Bacillariophyceae di perairan Teluk Kendari cukup tinggi (8.484 sel.L ( $\left.^{-1}\right)$ dibandingkan famili Crustacea (5.191 indvidu. $\mathrm{L}^{-1}$ ) dan makro-avertebrata bentik (351 individu.m ${ }^{-2}$ ) (Asriyana 2011). Kondisi lambung yang penuh di atas 75\% (Gambar 3) menunjukkan bahwa genera fitoplankton tersebut merupakan makanan yang penting untuk ikan kuniran. Selain itu, tidak ditemukannya kondisi lambung yang kosong saat sampling diduga mengindikasikan kuniran mempunyai laju pengosongan usus yang sebanding dengan jumlah makanan yang dicerna dan ikan tersebut makan setiap saat, seperti yang ditemukan pada ikan Sardinops sagax (Van der Lingen 1988) dan Sardina pilchardus (Cunha et al. 2005).

Komposisi makanan kuniran antara kelompok ukuran terlihat berbeda (uji KruskalWallis pada taraf kepercayaan 95\%, [P < 0,05; $\alpha$ $=5 \%, \mathrm{db}=\mathrm{n}-2])$ (Tabel 4). Jumlah variasi makanan yang dikonsumsi kuniran saat berukuran kecil lebih rendah dibanding saat berukuran sedang dan besar. Demikian pula hanya dengan indeks bagian terbesar (Ii) genus Thalassiothrix cukup tinggi saat berukuran kecil dan menurun dengan bertambahnya ukuran ikan. Tingginya 
fitoplankton yang dikonsumsi saat berukuran kecil disebabkan oleh fitoplankton tersebut merupakan anggota dari famili Bacillariophyceae yang mudah dicerna oleh ikan berukuran kecil (Lannan et al. 1983, Asriyana et al. 2004, Asriyana et al. 2010, Asriyana \& Syafei 2012).

Fitoplankton genus Thallasiothrix merupakan makanan dominan ikan kuniran untuk semua kelompok ukuran. Jenis makanan dominan merupakan jenis makanan yang memiliki kontribusi (volume) besar dalam saluran pencernaan ikan kuniran. Sebaliknya, makanan dominan dari kelompok zooplankton beralih dari genus Lucifer (saat berukuran kecil dan sedang) menjadi genus Microsetella (saat berukuran besar). Perubahan mangsa ikan kuniran dari genus Lucifer menjadi Microsetella saat berukuran besar diduga berkaitan dengan tingginya kandungan gizi dari Microsetella. Microsetella merupakan kelompok copepoda dari ordo Harpacticoida yang mempunyai kandungan gizi lebih tinggi dibandingkan jenis lainnya. Harpacticoida kaya akan EPA dan DHA serta tingkat produktivitasnya lebih tinggi dari Calanoida dan Cyclopoida. Selain itu juga mempunyai enzim-enzim seperti $\Delta-5, \Delta-6$ desaturase dan elongase yang diperlukan untuk mengubah asam lemak esensial rantai pendek (LNA18:3n3) menjadi kandungan asam lemak esensial rantai panjang DHA (22:6n3) dan EPA (20:5n3), serta omega 3 yang mengandung asam lemak tak jenuh (HUFA) tinggi (Nugraha \& Hismayasari 2011). Tingginya kandungan gizi yang dimiliki ordo ini diduga menjadi penyebab Microsetella menjadi mangsa ikan berukuran besar karena terkait dalam pemenuhan kebutuhan nutrisi. Selain itu ordo ini memiliki gerakan yang zig-zag meluncur pendek dan patah-patah, sehingga lebih menarik perhatian ikan daripada Rotifer dan Artemia (Lavens \& Sorgelos 1996). Model gerakan ini diduga menjadi daya tarik ikan berukuran besar untuk memangsa Microsetella. Kondisi ini berkaitan dengan kemampuan gerak ikan ukuran besar yang semakin meningkat sejalan dengan perkembangannya. Demikian pula halnya makanan dari kelompok makro-avertebrata bentik (Helisoma) yang hanya dikonsumsi oleh ikan berukuran besar. Kesukaan ikan ukuran besar terhadap mangsa ini diduga berkaitan dengan kebutuhan nutrisi dan kemampuan saluran pencernaan ikan ukuran besar dalam mencerna makanan dari genus ini. Helisoma merupakan ordo Basommatophora yaitu kelompok siput yang memiliki rongga mantel dari kalsium (Kunigelis \& Saleuddin 1986).

Meningkatnya ukuran ikan menyebabkan jumlah variasi makanan yang dikonsumsi semakin beragam. Hal ini menunjukkan bahwa dengan meningkatnya ukuran maka relung makanan ikan kuniran semakin besar dan diduga terkait dengan kebutuhan nutrisi dan kemampuan bergerak ikan yang semakin meningkat sejalan dengan perkembangan ikan (Nyegaard et al. 2004, Garcia \& Geraldi 2005). Peralihan makanan ontogenetik tidak hanya terjadi pada ikan kuniran, namun juga terlihat pada beberapa jenis ikan lainnya seperti ikan Citharichthys spilopterus (Rivera et al. 2000), Serrasalmus brandtii (Olivera et al. 2004), dan Nemipterus hexodon (Asriyana \& Syafei 2012).

Perubahan jenis organisme makanan kuniran tidak hanya terlihat berdasarkan ukuran, tetapi juga terlihat berdasarkan waktu pengamatan (uji Kruskal-Wallis pada taraf kepercayaan 95\%, $[\mathrm{P}<0,05 ; \alpha=5 \%, \mathrm{db}=\mathrm{n}-2])($ Tabel 5). Genera Thallasiothrix, Leptocylindrus, dan Calanus merupakan tiga genera yang sering ditemukan selama penelitian dengan frekuensi kehadiran sekitar 71-100\%. Sementara keberadaan jenis makanan lainnya selama waktu pengamatan hanya berkisar 14-57\%. Hal ini menunjukkan bahwa ketiga ge- 
nera tersebut mempunyai peranan penting sebagai makanan utama ikan kuniran. Kondisi tersebut berhubungan dengan ketersediaan genera Thallasiothrix, Leptocylindrus (kelas Bacillariophyceae) dan Calanus (kelas Crustacea) yang cukup melimpah di perairan Teluk Kendari. Makanan suatu jenis ikan selain dipengaruhi oleh habitat hidup ikan juga dipengaruhi oleh musim yang berkaitan dengan ketersediaan makanan di perairan (Popova 1978, Asriyana et al. 2004).

\section{Strategi pola makan}

Strategi pola makan berkaitan dengan kebiasaan makan yang salah satunya adalah mengenai bagaimana makanan tersebut diperoleh oleh suatu jenis ikan. Metode grafis Amundsen et al. (1996) menunjukkan bahwa ikan kuniran mengembangkan strategi pola makan campuran antara spesialis dan generalis dalam memperoleh mangsa di perairan. Strategi pola makan campuran tersebut dikembangkan oleh ikan berukuran kecil dan sedang, sementara ikan berukuran besar hanya mengembangkan strategi pola makan generalis. Keterbatasan dalam ruang gerak dan kemampuan organ pencernaan dalam mencerna makanan diduga merupakan penyebab diterapkannya strategi pola makan spesialis saat ikan berukuran kecil dan sedang. Thallasiothrix merupakan satu-satunya genus dari famili Bacillariophycea yang dimangsa oleh ikan saat berukuran kecil dengan strategi pola makan spesialis. Strategi pola makan spesialis dikembangkan oleh ikan dalam mencari makanan apabila kelimpahan makanan tersebut tinggi di perairan. Sebaliknya, saat kelimpahan makanan tersebut rendah, ikan akan mengembangkan strategi pola makan generalis. Kelimpahan mangsa dan karakteristik mangsa/bentuk tubuh merupakan variabel utama yang menentukan pilihan makanan pada ikan (Scenna et al. 2006, Johnson et al. 2007,
Sa'nchez-Herna'ndez 2011). Strategi spesialis merupakan strategi yang dikembangkan oleh ikan yang memiliki adaptasi morfologis dan perilaku yang sangat spesifik terhadap makanannya sehingga sangat efisien dalam mencari makan, sebaliknya strategi generalis dikembangkan jika makanan yang lebih disukai tidak tersedia (Steven et al. 2006). Pada ikan berukuran sedang, posisi Thalassiothrix digantikan oleh genera Coscinodiscus dan Licmophora yang dimanfaatkan dengan strategi spesialis. Hal ini berkaitan dengan kelimpahan spesifik genera tersebut lebih tinggi ( $\geq 50 \%$ ) daripada genus Thalassiothrix. Penggunaan dua atau lebih sumber daya makanan diduga merupakan salah satu strategi yang dikembangkan untuk menghindari terjadinya persaingan. Sementara ikan berukuran besar mengembangkan strategi generalis yang berkaitan dengan kelimpahan spesifik makanan yang rendah $(\leq 50 \%)$.

Secara umum, ikan kuniran mengembangkan strategi generalis pada semua bulan pengamatan, kecuali bulan Juli, Agustus, dan Oktober. Saat tersebut, kuniran juga mengembangkan strategi spesialis untuk satu jenis mangsa yaitu genus Thalassiothrix. Kondisi ini berkaitan dengan kelimpahan spesifik mangsa relatif rendah $(\leq 50 \%)$, kecuali genus Thalassiothrix yang $\geq 50 \%$. Ketika pemangsa memanfaatkan mangsa yang berlimpah, luas relung makanan pemangsa tersebut menjadi sempit dan bersifat spesialis terhadap mangsa tersebut. Persediaan organisme makanan tinggi di perairan akan menjadi faktor yang mengakibatkan luas relung makanan menjadi rendah (Hajisamaea et al. 2003, Irawati \& Asriyana 2007).

Walaupun kisaran nilai luas relung ikan kuniran berdasarkan kelompok ukuran relatif kecil $\left(B_{i}=0,15-0,28\right)$, namun ikan kuniran umumnya mengembangkan strategi generalis untuk 
semua jenis mangsa kecuali mangsa dari genus Thallasiothrix. Luas relung makanan menggambarkan besaran sumber daya yang mampu dimanfaatkan oleh kelompok ikan. Variasi makanan yang besar tidak menjamin akan memberikan kisaran luas relung yang besar, karena nilai luas relung juga dipengaruhi oleh seberapa besar ikan tersebut dapat memanfaatkan sumber daya yang tersedia. Apabila proporsi sumber daya makanan yang dimanfaatkan tidak sama untuk setiap jenis mangsa, maka luas relung akan memberikan suatu kisaran yang relatif sempit (Giller 1984). Hal ini menunjukkan bahwa ikan kuniran memanfaatkan mangsa dengan proporsi yang tidak sama untuk setiap jenis mangsa sehingga nilai luas relungnya berada pada kisaran yang lebih sempit. Suatu organisme dikatakan memiliki luas relung yang besar (generalis) jika ia memanfaatkan seluruh sumber daya pakan yang tersedia secara merata sedangkan jika memanfaatkan hanya beberapa sumber daya makanan yang ada, ia bersifat spesialis (Colwell \& Futuyama 1971).

Strategi pola makan campuran antara generalis dan spesialis juga ditemukan pada ikan Synodus foetens di Teluk Mexico (Cruz-Escalona et al. 2005), Syngnathus folletti di Laguna Patos, Brazil (Garcia et al. 2005), ikan goby Aphia minuta di Laut Adriatic (La Mesa et al. 2008) dan ikan demersal Elasmobranchii di Laut Balearic (Valls et al. 2011). Sebaliknya ikan pari, Bathyraja macloviana (Scenna et al. 2006) hanya mengembangkan strategi pola makan spesialis dalam mengambil mangsanya di perairan.

\section{Simpulan}

Komposisi makanan ikan kuniran yang terdiri atas fitoplankton, zooplankton, makroavertebrata bentik, dan detritus. Fitoplankton genus Thallasiothrix merupakan makanan dominan pada ikan kuniran. Komposisi makanan menga- lami perubahan signifikan sejalan dengan bertambahnya ukuran tubuh dan waktu. Dalam memanfaatkan makanan di perairan Teluk Kendari, kuniran mengembangkan strategi pola makan campuran antara generalis dan spesialis. Strategi pola makan generalis dikembangkan untuk memperoleh semua jenis mangsa, kecuali mangsa Thallasiothrix diperoleh dengan strategi pola makan spesialis.

\section{Persantunan}

Penulis mengucapkan terima kasih kepada Kementerian Riset, Teknologi dan Pendidikan Tinggi atas bantuan dana penelitian dalam skim hibah bersaing Tahun 2015 dan 2016. Penulis juga mengucapkan terima kasih kepada nelayan Teluk Kendari atas bantuannya dalam pengumpulan data di lapangan; Fakultas Perikanan dan Ilmu Kelautan Universitas Halu Oleo atas seluruh dukungan fasilitas dalam penyelesaian penelitian ini.

\section{Daftar Pustaka}

Amundsen PA, Gabler HM, Staldvik FJ. 1996. A new approach to graphical analysis of feeding strategy from stomach contents data modification of the Costello (1990) method. Journal of Fish Biology, 48(4): 607614.

Arslan M, Ismen A. 2013. Age, growth and reproduction of Mullus surmuletus (Linnaeus, 1758) in Saros Bay (Northern Aegean Sea). Journal of the Black Sea/Mediterranean Environment, 19(2): 217-233.

Asriyana, Sulistiono, Rahardjo MF. 2004. Studi kebiasaan makanan ikan tembang (Fam. Clupeidae) di perairan Teluk Kendari, Sulawesi Tenggara. Jurnal Iktiologi Indonesia, 4(1): 43-50.

Asriyana, Rahardjo MF, Sukimin S, Lumban Batu DTF, Kartamihardja ES. 2009. Keanekaragaman ikan di perairan Teluk Kendari, Sulawesi Tenggara. Jurnal Iktiologi Indonesia, 9(2): 97-112. 
Asriyana, Rahardjo MF, Lumban Batu DTF, Kartamihardja ES. 2010. Makanan ikan japuh, Dussumieria acuta Val. 1847 (Famili Clupeidae) di perairan Teluk Kendari, Sulawesi Tenggara. Jurnal Iktiologi Indonesia, 10(1): 93-99.

Asriyana. 2011. Interaksi trofik komunitas ikan sebagai dasar pengelolaan sumber daya ikan di perairan Teluk Kendari, Sulawesi Tenggara. Disertasi. Sekolah Pasacasarjana, Institut Pertanian Bogor. Bogor. 106p.

Asriyana, Syafei LS. 2012. Perubahan ontogenetik makanan ikan kurisi, Nemipterus hexodon (Family Nemipteridae) di perairan Teluk Kendari, Sulawesi Tenggara. Jurnal Iktiologi Indonesia, 12(1): 49-57.

Asriyana, Irawati N. 2017. Pertumbuhan dan faktor kondisi ikan kuniran, Upeneus sulphureus di perairan Teluk Kendari. Jurnal Aquasains, 6(1): 527-534.

Baker R, Sheaves M. 2005. Redefining the piscivore assemblage of shallow estuarine nursery habitats. Marine Ecology Progress Series, 291(1):197-213.

Beck MW, Heck KL, Able KW. 2001. The Identification, conservation, and management of estuarine and marine nurseries for fish and invertebrates: A better understanding of the habitats that serve as nurseries for marine species and the factors that create sitespecific variability in nursery quality will improve conservation and management of these areas. Bioscience, 51(8): 633-641.

Blaber SJM, Blaber TG. 1980. Factors affecting the distribution of juvenile estuarine and inshore fish. Journal of Fish Biology, 17(2): 143-162.

Boraey FA, Soliman FM. 1987. Length-weight relationship, relative condition, and food and feeding habits of the goatfish Upeneus sulphureus Cuv. \& Val. in Safaga Bay of the Red Sea. Journal of the Inland Fisheries Society of India, 19(2): 47-52.

Burhanuddin, Martosewojo S, Djamali A, Moeljanto R. 1984. Perikanan demersal di Indonesia. Lembaga Oseanologi Nasional LIPI. Jakarta. 63p.

Celik O, Torcu H. 2000. Investigations on the biology of red mullet (Mullus barbatus L., 1758) in Edremit Bay, Aegean Sea, Turkey. Turkish Journal of Veterinary and Animal, 24 (3): 287--295.
Chérif M, Ben Amor MM, Selmi S, Gharbi H, Missaoui H, Capapé C. 2011. Food and feeding habits of the red mullet, Mullus barbatus (Actinopterygii: Perciformes: Mullidae), off the northern Tunisian coast (central Mediterranean). Acta Ichthyologica et Piscatoria, 41(2): 109-116.

Colwell RK, Futuyama DJ. 1971. On the measurement of niche breadth and overlap. Ecology, 52(4): 567-579.

Crowder LB, Cooper WE. 1982. Habitat structural complexity and the interaction between bluegills and their prey. Ecology, 63(6): 1802-1813.

Cruz-Escalona V. H., Peterson M. S., CamposDavila L., Zetina-Rejon M., 2005 Feeding habits and trophic morphology of inshore lizardfish (Synodus foetens) on the central continental shelf off Veracruz, Gulf of Mexico. Journal of Applied Ichthyology 21(6): 525-530.

Cunha ME, Garrido S, Pissarra J. 2005. The use of stomach fullness and colour indices to assess Sardina pilchardus feeding. Journal of the Marine Biological Association of the United Kingdom, 85(2): 425-431.

Diandria D, Ernawati T. 2011. Beberapa aspek biologi ikan kuniran (Upeneus sulphureus) di perairan Tegal dan sekitarnya. Bawal, 3(4): 261-267.

Edworthy C, Strydom N. 2016. Habitat partitioning by juvenile fishes in a temperate estuarine nursery, South Africa. Scientia Marina, 80(2): 151-161.

Effendie MI. 1979. Metoda Biologi Perikanan. Yayasan Dewi Sri. Bogor. 112 p.

Elliott M, Hemingway K (editors). 2002. Fishes in Estuaries. Blackwell Science Ltd. London. $636 \mathrm{p}$.

Garcia AM, Geraldi RM. 2005. Diet composition and feeding strategy of the southern pipefish Syngnathus folletti in a Widgeon Grass Bed of the Patos Lagoon Estuary, RS, Brazil. Neotropical Ichthyology, 3(3): 427-432.

Giller PS. 1984. Community structure and the niche. Chapman and Hall. London. 176 p.

Gosner KL. 1971. Guide to Identification of Marine and Estuarine Invertebrates. John Wiley and Sons. New York. 693p. 
Green BC, Smith DJ, Earley SE, Hepburn LJ, Underwood GJC. 2009. Seasonal changes in community composition and trophic structure of fish populations of five salt marshes along the Essex coastline, United Kingdom. Estuarine, Coastal and Shelf Science, 85(2): 241-246.

Hajisamaea S, Choua LM, Ibrahim S. 2003. Feeding habits and trophic organization of the fish community in shallow waters of an impacted tropical habitat. Estuarine, Coastal and Shelf Science, 58(1): 89-98.

Higgins RP, Thiel H (editors). 1988. Introduction to the Study of Meiofauna. Smithsonian Institution Press. Washington. 464p.

Hinz H, Kroncke I, Ehrich S. 2005. The Feeding Strategy of Dab Limanda limanda in the Southern North Sea: Linking Stomach Contents to Prey Availability in the Environment. Journal of Fish Biology, 67(Supplement sB): 125-145.

Irawati N, Asriyana. 2007. Abudance of phytoplankton in Kendari Bay, Southeast Sulawesi. Aplikasi Sains, 10(1): 25-29.

Jaureguizar AJ, Milessi AC. 2008. Assessing the sources of the fishing down marine food web process in the Argentinean-Uruguayan common fishing zone. Scientia Marina, 72(1): 25-36.

Jin B, Fu C, Zhong J. 2007. Fish utilization of a salt marsh intertidal creek in the Yangtze River estuary, China. Estuarine, Coastal and Shelf Science, 73(3-4): 844-852.

Johnson RL, Coghlan SM, Harmon T. 2007. Spatial and temporal variation in prey selection of brown trout in a cold Arkansas tailwater. Ecology of Freshwater Fish, 16(3): 373384.

Karakassis I, Pitta P, Krom MD. 2005. Contribution of fish farming to the nutrient loading of the Mediterranean. Scientia Marina, 69(2): 313-321.

Kherraz A, Kherraz A, Benghali S, Mouffok S, Boutiba Z. 2014. Age and growth of Mullus surmuletus (L.) in Mostaganem coast, Northwest Algeria. Journal of Biodiversity and Environmental Sciences, 5(2): 37-43.

Krebs CJ. 1989. Ecological Methodology. Harper \& Row Publishers, Inc. New York. 654 p.

Kunigelis SC, Saleuddin ASM. 1986. Reproduction in the freshwater gastropod Helisoma: involvement of prostaglandin in egg production. International Journal of Invertebrate Reproduction and Development 10(2): 159-167.

La Mesa M, Borme D, Tirelli V, Di Poi E, Legovini S, Umani SF. 2008. Feeding ecology of the transparent goby Aphia minuta (Pisces: Gobiidae) in the northwestern Adriatic Sea. Scientia Marina, 72(1): 99-108.

Labropoulou M, Papadopoulou-Smith K-N. 1999. Foraging behaviour patterns of four sympatric demersal fishes. Estuarine, Coastal and Shelf Science, 49(Supplement 1): 99--108.

Lagler KF, Bardach JE, Miller RR. 1962. Ichthyology. John Wiley, New York. 545p.

Lannan JE, Smitherman RO, Tchobanoglous G. 1983. Principles and Practices of Pond Culture: A State of the Art Review. Pond Dinamic/Aquaculture CRSP. Program Manajemen Office Oregon State University, Marine Science Center: Oregon. p45-50.

Lavens P, Sorgelos P. 1996. Manual on the production and use of live food for aquaculture. FAO Fisheries Technical Paper, No. 301, 295 pp.

Metin G. 2005. Reproduction characteristics of red mullet (Mullus barbatus L., 1758) in Izmir Bay (in Turkish). Fisheries and Aquatic Sciences, 22(1-2): 225-228.

Nanjo K, Kohno H, Nakamura Y. 2014. Differences in fish assemblage structure between vegetated and unvegetated microhabitats in relation to food abundance patterns in a mangrove creek. Fisheries Science, 80(1): 21-41.

Natarajan AV, Jhingran AD. 1961. Index of preponderance-a method of grading the food elements in the stomach analysis of fishes. Indian Journal of Fisheries, 8(1): 54-59.

Novakowski GC, Hahn NS, Fugi R. 2008. Diet seasonality and food overlap of the fish assemblage in a pantanal pond. Neotropical Ichthyology, 6(4):567-576.

Nugraha MFI, Hismayasari IB. 2011. Copepoda: sumbu kelangsungan biota akuatik dan kontribusinya untuk akuakultur. Media Akuakultur, 6(1): 13-20.

Nyegaard M, Arkhipkin A, Brickle P. 2004. Variation in the diet of Genypterus blacodes 
(Ophidiidae) around the Falkland Islands. Journal of Fish Biology, 65(3): 666-682.

Olivera AK, Alvim MCC, Peret AC, Alves CBM. 2004. Diet shifts related to body size of the pirembeba Serrasalmus brandtIi Lutken,1875 (Osteichthyes, Serrasalminae) in the Cajuru Reservoir, Sao Fransisco River Basin, Brazil. Brazilian Journal of Biology, 64 (1): 117-124.

Orpin AR, Peter VR, Thomas SE, Anthony KRN, Marshall P, Oliver J. 2004. Natural turbidity variability and weather forecasts in risk management of anthropogenic sediment discharge near sensitive environments. Marine Pollution Bulletin, 49(7-8): 602-612.

Popova OA. 1978. The role of predaceous fish in ecosystem. In Gerking SD (editor). Ecology of freshwater fish production. Blackwell Scientific Publication. Oxford. p 215-249.

Rahardjo MF, Brojo M, Simanjuntak CPH, Zahid A. 2006. Komposisi makanan ikan selanget, Anodontostoma chacundata HB 1822 (Pisces: Clupeidae) di Perairan Pantai Mayangan, Jawa Barat. Jurnal Perikanan, 8(2): 159-166.

Rivera MC, Kobelkowsky A, Chavez AM. 2000. Feeding biology of the flatfish Citharichthys spilopterus (Bothidae) in tropical estuary of Mexico. Journal of Applied Ichthyology, 16(2): 73-78.

Sa'nchez-Herna'ndez J, Vieira-Lanero R, Servia MJ, Cobo F. 2011. Feeding habits of four sympatric fish species in the Iberian Peninsula: keys to understanding coexistence using prey traits. Hydrobiologia, 667(1): 119-132.

Santoso S. 2003. SPSS Versi 10: Mengolah Data Statistik Secara Profesional. Elex Media Komputindo. Jakarta. p 305-428.

Scenna LB, Garci'a de la Rosa SB, Di'az de Astarloa JM. 2006. Trophic ecology of the Patagonian skate, Bathyraja macloviana, on the Argentine continental shelf. ICES Journal of Marine Science, 63(1): 867-874
Sjafei DS, Susilawati R. 2001. Beberapa aspek biologi ikan biji nangka (Upeneus moluccensis Blkr.) di perairan Teluk Labuan, Banten. Jurnal Iktiologi Indonesia, 1(1): 35-39.

Sokal RR, Rohlf FJ. 1995. Biometry. W.H. Freeman and Company. New York. 887p.

Stevens M, Maes J, Ollevier F. 2006. Taking potluck: trophic guild structure and feeding strategy of an intertidal fish assemblage. In: Stevens M. (ed.), Intertidal and BasinWide Habitat Use of Fishes in the Scheldt Estuary. Faculteit Wetenschappen, Geel Huis, Kasteelpark Arenberg 11, $3001 \mathrm{He}-$ verlee (Leuven). pp 37-59.

Sumiono B, Nuraini S. 2007. Beberapa parameter biologi ikan kuniran (Upeneus sulphureus) hasil tangkapan cantrang yang didaratkan di Brondong Jawa Timur. Jurnal Iktiologi Indonesia, 7(2): 83-88.

Tomas CR (editor). 1997. Identifying Marine Phytoplankton. Academic Press: The United States of America. $858 \mathrm{p}$.

Valls M, Quetglas A, Ordines F, Moranta J. 2011. Feeding ecology of demersal elasmobranchs from the shelf and slope off the Balearic Sea (western Mediterranean). Scientia Marina, 75(4):633-639.

Van der Lingen CD. 1998. Gastric evacuation, feeding periodicity and daily ration of sardine Sardinops sagax in the southern Benguela upwelling ecosystem. South African Journal of Marine Science, 19(1): 305-316.

Wang M, Huang Z Shi F, Wang W. 2009. Are vegetated areas mangroves attractive to juvenile and small fish? The case of Dongzhaigang Bay, Hainan Island, China. Estuarine, Coastal and Shelf Science, 85(2): 208-216.

Yamaji EE. 1979. Ilustration of the Marine Plankton of Japan. Hoikusha Publishing: Japan. 536p. 
